\title{
Antibiotic resistance surveillance of Helicobacter pylori at the Biobío region (Chile) in a decade
}

\author{
Cristian PARRA-SEPÚLVEDA', José S MERINO² ${ }^{2}$ Katia SÁEZ-CARRILLO ${ }^{3}$, Carlos GONZÁLEZ ${ }^{1}$ and \\ Apolinaria GARCÍA-CANCINO ${ }^{1}$
}

ABSTRACT - Background - Helicobacter pylori infection in Chile remains as a public and private health-care system's challenge, with a prevalence of the infection over $70 \%$. Nowadays, antibiotic treatment of the infection is mandatory to prevent the arising of severe associated diseases but failures in the eradication therapy mainly due to clarithromycin resistance has been observed worldwide and first line eradication therapy seems to be not effective anymore in several geographical areas. Thus, health-care systems are committed to maintain an epidemiological surveillance upon the evolution of the antibiotic resistance of this priority 2 pathogen. Objective - This work reports a 10 years surveillance of the primary antibiotic resistance of $H$. pylori clinical isolates at the Biobío region-Chile, and the evolution of resistance toward amoxicillin, clarithromycin, levofloxacin, metronidazole, and tetracycline among the species. Methods - H. pylori strains were investigated during the periods 2005-2007 (1435 patients analysed) and 2015-2017 (220 patients analysed) by inoculating a saline homogenate biopsy onto the surface of Columbia agar (Oxoid, Basingstoke, UK) - supplemented with $7 \%$ horse red blood cells plus DENT inhibitor (Oxoid, Basingstoke, UK) - following by incubation at $37^{\circ} \mathrm{C}$ under $10 \% \mathrm{CO}_{2}$ atmosphere for five days. Antibiotic resistance pattern of the isolates was assessed using the disk diffusion test in Müeller-Hinton agar supplemented with 7\% horse red blood cells followed by incubation for further three days under $10 \% \mathrm{CO}_{2}$ atmosphere. Statistical analysis was done using the SPSS v22 software and $P$ values $<0.05$ were considered statistically significant. Results - A total of $41 \%$ of 1435 patients were detected to be infected with $H$. pylori by bacteriological culture in 2005-2007 period, meanwhile 32.7\% from 220 patients were also infected in 2015-2017 period. The clinical isolates of $H$. pylori are mostly susceptible to amoxicillin and tetracycline (both over $98 \%$ of strains), but less susceptible to levofloxacin in both periods analysed (over $79 \%$ of the strains). On the other hand, metronidazole continuous showing the highest score of resistant isolates (over $40 \%$ of resistant strains), although an $18 \%$ fewer resistant strains were observed in 2015-2017 period. Clarithromycin, the key antibiotic in eradication therapies, has an increased frequency of resistant strain isolated in the decade (22.5\% in 2005-2007 and 29.2\% in 2015-2017). Multidrug resistant strains (two, three and four antibiotics) were also detected in both periods with the highest scores for simultaneous resistance to clarithromycin-metronidazole (18\%) and clarithromycin-metronidazole-levofloxacin (12.5\%) resistant strains. According to gender, the isolates resistant to amoxicillin, clarithromycin and metronidazole were more frequent in female, with a specific increment in amoxicillin and clarithromycin resistance. Conclusion - The frequency of clarithromycin resistance $(29.2 \%)$ detected in 2015-2017 suggests that conventional triple therapy is no longer effective in this region.

HEADINGS - Helicobacter pylori, drug effects. Helicobacter infections. Anti-bacterial agents. Bacterial drug resistance. Clarithromycin. Men. Women. Chile.

\section{INTRODUCTION}

Chronic Helicobacter pylori infection is causally related to benign and serious malignant upper gastrointestinal diseases, including peptic ulcer, gastric mucosa-associated lymphoid tissue lymphoma, and gastric cancer. Conversely, eradication of H. pylori is associated with ulcer healing, regression of mucosa-associated lymphoid tissue lymphoma, and decreased cancer risk ${ }^{(1)}$. Chile has one of the highest rates of $H$. pylori infection in the world ${ }^{(2,3)}$ and different studies have shown a prevalence of infection ranging from $60 \%$ to $79 \%$, according to socio-economic, educational and health conditions of the population studied ${ }^{(4)}$. In addition, Merino et al. ${ }^{(5)}$ suggested that in Chile exists an increased risk of infection by $H$. pylori during the first year of life (up to $23.9 \%$ ). Moreover, gastric adenocarcinoma and the high prevalence of $H$. pylori at younger ages are a major cause of cancer-related mortality ${ }^{(2)}$.
Successful treatment for $H$. pylori infection requires multidrug regimens, which are frequently based on clarithromycin as the central component, and the first-line therapy for eradicating this pathogen includes a widespread regime, which involves the administration of a combination of a proton pump inhibitor (PPI) plus clarithromycin and metronidazole or amoxicillin ${ }^{(6)}$. However, eradication rates vary with the level of antibiotic resistance prevalence in a particular geographical area and the use of clarithromycin without previous susceptibility testing is not recommended in populations with more than $15 \%-20 \%$ prevalence of resistant isolates $^{(1)}$. In addition, the Maastricht $\mathrm{V}$ Consensus recommended that susceptibility tests should be performed too in these areas at least after a treatment failure ${ }^{(7,8)}$.

Special attention is conceited by clarithromycin-resistant isolates of $H$. pylori - recognized by the World Health Organisation as a high priority species (priority 2) in clinical issues - for which

Declared conflict of interest of all authors: none

Disclosure of funding: This work received financial support from Grant Fondef D03i1105 and Grants from the Universidad de Concepción-Chile.

Universidad de Concepción, Facultad de Ciencias Biológicas, Departamento de Microbiología, Concepción, Chile. ${ }^{2}$ Universidad de las Américas, Facultad de Medicina Veterinaria y Agronomía, Concepción, Chile. ${ }^{3}$ Universidad de Concepción, Facultad de Ciencias Físicas y Matemáticas, Departamento de Estadística, Concepción, Chile.

Corresponding author: Apolinaria García-Cancino. E-mail: apgarcia@udec.cl 
new antibiotics are needed ${ }^{(9)}$. In Chile, Serrano et al. ${ }^{(10)}$ pointed out the high prevalence of mutation $\mathrm{A} 2143 \mathrm{G}$ in clinical isolates from paediatric patients as the main responsible of $H$. pylori clarithromycin resistance and that it is concomitantly associated to failure in eradicating this infection. On the other hand, the last Florence Consensus Report (Maastricht V) also established that all individuals which have gastritis produced by $H$. pylori should be treated to avoid progression of associated diseases ${ }^{(7)}$. Hence, the antibiotic resistance prevalence of $H$. pylori in geographical areas with high rate of infection and the antibiotic treatment scheme to be used are critical for the successful eradication therapy. Moreover, antibiotic resistance surveillance is also mandatory, especially for detecting clarithromycin resistance among clinical isolates. In this work we inform a 10 years evolution of the antibiotic primary resistance to amoxicillin, clarithromycin, metronidazole, tetracycline, and levofloxacin among clinical isolates of $H$. pylori at the Biobío-Chile geographic region.

\section{METHODS}

\section{Patients and inclusion criteria}

Gastric biopsies from 1655 patients submitted to upper gastric endoscopy (UGE) procedure in two periods - first period 2005-2007 (1435 individuals) and second period 2015-2017 (220 individuals) - were analysed for isolating $H$. pylori. The inclusion criteria were patients that did not receive previously an $H$. pylori eradication therapy and did not consume antibiotics or proton pump inhibitor in the previous month before the UGE procedure. For the antibiotic resistance study, only those patients whose biopsies were positive for $H$. pylori bacteriological culture were finally considered in the analyses.

\section{Isolation and identification of $\boldsymbol{H}$. pylori}

Gastric biopsies samples (ca. 2 mm diameter) were processed at the laboratory of Bacterial Pathogenicity, University of Concepcion-Chile. Briefly, each biopsy was grounded in $0.5 \mathrm{~mL}$ of saline solution and spread onto the surface of Columbia agar (Oxoid, Basingstoke, UK) supplemented with 7\% horse red blood cells plus DENT inhibitor (Oxoid, Basingstoke, UK). Cultures were incubated at $37^{\circ} \mathrm{C}$ during $72 \mathrm{~h}$ under microaerophilic conditions $\left(10 \% \mathrm{CO}_{2}\right.$; Campygen - Oxoid, Basingstoke, UK). Negative cultures were further incubated for seven additional days prior to be considered negative for $H$. pylori presence. Bacterial identification was done by Gram stain followed by urease, catalase and oxidase tests ${ }^{(11)}$.

\section{Antibiotics}

Amoxicillin, clarithromycin, levofloxacin, metronidazole and tetracycline were investigated. All antibiotics were obtained from Oxoid (Basingstoke, UK). The total number of clinical isolates assayed per antibiotic during the period 2005-2007 were 299 strains for amoxicillin, 333 strains for clarithromycin, 321 strains for levofloxacin, 364 strains for metronidazole, and 311 strains for tetracycline. In the second period, years 2015-2017, a total of 72 clinical isolates were assayed per antibiotic.

\section{Susceptibility test}

The disk diffusion test was done according to Lang and García $^{(12)}$. Antibiotics disk concentration used and their breakpoint criteria for resistance per each antibiotic were as follow: amoxicillin
(10 $\mu \mathrm{g}$ disk), diameter of inhibition zone $\leq 25 \mathrm{~mm}$; clarithromycin (15 $\mu \mathrm{g}$ disk), diameter of inhibition zone $\leq 21 \mathrm{~mm}$; tetracycline $(30 \mu \mathrm{g}$ disk), diameter of inhibition zone $\leq 25 \mathrm{~mm}$. The breakpoint criteria for metronidazole ( $5 \mu \mathrm{g}$ disk) was: resistant, diameter of inhibition zone $<16 \mathrm{~mm}$; intermediate, diameter of inhibition zone $16-21 \mathrm{~mm}$, and susceptible, diameter of inhibition zone $>21 \mathrm{~mm}^{(13,14)}$.

Because no criteria was established for levofloxacin in disk diffusion test upon $H$. pylori until 2011, in the first period of analysis the criteria proposed for Gram-negative bacteria was used ${ }^{(15)}$, with $5 \mu \mathrm{g}$ disk potency. The breakpoint criterium for resistance was, diameter of inhibition zone $\leq 12 \mathrm{~mm}^{(16)}$.

\section{Statistical analysis}

The analyses of the data base were done using SPSS v22 software. The categorical variables were represented by the frequency and percentage of each one of their classes. The chi square test was used to determine differences in percentages and the MannWhitney $\mathrm{U}$ test was used to compare numerical variables. Level of significance used was 0.05 .

\section{RESULTS}

Five hundred and seventy-five patients $(40.1 \%)$ were positive for $H$. pylori infection in period 2005-2007, as determined by bacteriological culture, and 72 patients $(32.7 \%)$ were positive in period 2015-2017 (TABLE 1). This decrease of infected patients in the second period of analysis was mostly due to a lower infection fraction of the female group ( $56.7 \%$ to $52.8 \%$ ), meanwhile the infected men fraction increased during the 10 years period considered in the analysis $(43.3 \%$ to $47.2 \%)$. The age average of infection in the two periods (TABLE 1) was similar, and the minor differences (47 and 50.6 years old) were not statistically significant $(P=0.063)$. On the other hand, analyses by age among each gender (TABLE 2) showed that female infection has a peak in the 41-50 years old group $(45.2 \%)$ in $2005-2007$, while men showed the peak in the group of 51-60 years old in the same period (46.9\%). In contrast, during period 2015-2017 male group showed the highest score of infected individuals between age 21 and 40 years old (TABLE 2). Interestingly, during $2005-2007$ both a $47.2 \%$ of male individuals under 20 years old and $50 \%$ of female individuals over 80 years old were also infected.

TABLE 1. Demographic data of patients included in the analyses.

\begin{tabular}{lcc}
\hline \multirow{2}{*}{ Data } & \multicolumn{2}{c}{ Number of patients } \\
\cline { 2 - 3 } & $2005-07$ & $2015-17$ \\
\hline Patients analyzed & $1435(100 \%)$ & $220(100 \%)$ \\
Age range (average) & $11-89$ & $\begin{array}{c}14-88 \\
\text { Infected patients }\end{array}$ \\
Female infected fraction & $326(56.7 \%)$ & $38(52.8 \%)$ \\
Male infected fraction & $249(43.3 \%)$ & $34(47.2 \%)$ \\
\hline
\end{tabular}


TABLE 2. Percentage of individuals infected with Helicobacter pylori per age group according to gender.

\begin{tabular}{|c|c|c|c|c|c|c|}
\hline \multirow{3}{*}{$\begin{array}{l}\text { Age group } \\
\text { Years old }\end{array}$} & \multicolumn{6}{|c|}{ Percentage of infected individuals among gender } \\
\hline & \multicolumn{2}{|c|}{ Female + Male } & \multicolumn{2}{|c|}{ Female } & \multicolumn{2}{|c|}{ Male } \\
\hline & 2005-07 & $2015-17$ & 2005-07 & $2015-17$ & 2005-07 & $2015-17$ \\
\hline $21-30$ & $36.4(55 / 151)$ & $40.0(8 / 20)$ & $32.5(26 / 80)$ & $25.0(3 / 12)$ & $40.8(29 / 71)$ & $62.5(5 / 8)$ \\
\hline $31-40$ & $39.7(72 / 181)$ & $44.1(15 / 34)$ & $37.9(33 / 87)$ & $26.7(4 / 15)$ & $41.5(39 / 94)$ & $57.9(11 / 19)$ \\
\hline $61-70$ & $35.2(57 / 162)$ & $19.0(8 / 42)$ & $40.0(38 / 95)$ & $15.4(4 / 26)$ & $28.4(19 / 67)$ & $25.0(4 / 16)$ \\
\hline $71-80$ & $30.7(26 / 85)$ & $7.7(1 / 13)$ & $35.5(16 / 45)$ & $12.5(1 / 8)$ & $25.0(10 / 40)$ & $0(0 / 5)$ \\
\hline $81-90$ & $41.2(14 / 34)$ & $100(1 / 1)$ & $50.0(11 / 22)$ & $100(1 / 1)$ & $25.0(3 / 12)$ & $0(0)$ \\
\hline Total & $40.1(575 / 1435)$ & $32.7(72 / 220)$ & $40.3(326 / 809)$ & $27.7(38 / 137)$ & $39.7(249 / 626)$ & $40.9(34 / 83)$ \\
\hline
\end{tabular}

Amoxicillin resistant strains isolated in both periods were of low frequency ( $2 \%$ and $4.2 \%$, respectively) (TABLE 3$)$. A similar behaviour with tetracycline resistance was observed, because only $1 \%$ and $1.4 \%$ of the strains showed to be resistant, respectively. On the other hand, a mild increase $(6.7 \%)$ in the frequency of clarithromycin resistant strains was observed, with frequencies of $22.5 \%$ and $29.2 \%$ per period, respectively. Regarding levofloxacin, an increase $(5.5 \%)$ of resistant strains isolated was detected, with a frequency of 15.3 and $20.8 \%$ per period. Unexpectedly, a significant decrease $(18 \%, P=0.005)$ in the frequency for metronidazole resistant strains isolated $(55.5 \%$ to $37.5 \%)$ was observed too.

TABLE 3. Susceptible and resistant strains to antibiotics used in the eradication therapy of Helicobacter pylori.

\begin{tabular}{lcccc}
\hline \multirow{2}{*}{ Antibiotic } & \multicolumn{3}{c}{ Percentage of strains (number) } \\
\cline { 2 - 5 } & \multicolumn{2}{c}{ Susceptible } & \multicolumn{2}{c}{ Resistant } \\
\cline { 2 - 5 } & $2005-07$ & $2015-17$ & $2005-7$ & $2015-17$ \\
\hline Amoxicillin & $98.0(293)$ & $95.8(69)$ & $2(6)$ & $4.2(3)$ \\
Clarithromycin & $77.5(258)$ & $70.8(51)$ & $22.5(75)$ & $29.2(21)$ \\
Levofloxacin & $84.7(272)$ & $79.1(57)$ & $15.3(49)$ & $20.8(15)$ \\
Metronidazole & $44.5(162)$ & $62.5(45)$ & $55.5(202)$ & $37.5(27)$ \\
Tetracycline & $99.0(377)$ & $98.6(71)$ & $1.0(4)$ & $1.4(1)$ \\
\hline
\end{tabular}

Simultaneous resistance to two antibiotics was observed among clinical isolates during the 2005-2007 period (TABLE 4), with increased prevalence of clarithromycin-metronidazole resistance $(5.8 \%)$, levofloxacin-metronidazole $(5.5 \%)$ and clarithromycinlevofloxacin $(9.2 \%)$ for the $2015-2017$ period. Moreover, in this period three and four antibiotic resistant strains were also isolated, with the highest frequency of isolation for the phenotype clarithromycin-levofloxacin-metronidazole resistance (2.2\%). Also, resistance frequency of $18 \%$ for clarithromycin-metronidazole and $12.5 \%$ for both levofloxacin-metronidazole resistance and clarithromycin-levofloxacin were detected too. In addition, isolates resistant to three and four antibiotics were also detected, with the highest score for clarithromycin-levofloxacin-metronidazole isolates $(12.5 \%)$.
TABLE 4. Isolation frequency of multi-resistant Helicobacter pylori strains in the decade.

\begin{tabular}{lccc}
\hline \multirow{2}{*}{$\begin{array}{l}\text { Phenotype of } \\
\text { resistance }\end{array}$} & \multicolumn{2}{c}{$\begin{array}{c}\text { Percentage of strains in } \\
\text { periods }\end{array}$} & $\begin{array}{c}\text { Increase in } \\
\text { isolation } \\
\text { frequency }\end{array}$ \\
\cline { 2 - 3 } & $\begin{array}{c}2005-07 \\
{[\mathrm{n}=271]}\end{array}$ & $\begin{array}{c}2015-17 \\
{[\mathrm{n}=72]}\end{array}$ & \\
\hline AMX-CLR & $0.7(2)$ & $2.8(2)$ & 2.1 \\
AMX-LEV & $1.5(4)$ & $4.2(3)$ & 2.7 \\
AMX-MTZ & $2.2(6)$ & $4.2(3)$ & 2.0 \\
CLA-LEV & $3.3(9)$ & $12.5(9)$ & 9.2 \\
CLA-MTZ & $12.2(33)$ & $18(13)$ & 5.8 \\
LEV-MTZ & $7(19)$ & $12.5(9)$ & 5.5 \\
& & & \\
AMX-CLA-LEV & $0.4(1)$ & $2.8(2)$ & 2.4 \\
AMX-CLA-MTZ & $1.1(3)$ & $2.8(2)$ & 1.7 \\
CLA-LEV-MTZ & $2.2(6)$ & $12.5(9)$ & 10.3 \\
& & & \\
AMX-CLA-LEV-MTZ & $0.4(1)$ & $2.8(2)$ & 2.4 \\
\hline
\end{tabular}

The frequency of isolation of $H$. pylori resistant strains among genders also varied in both periods. Thus, among female an increase of $1.8 \%$ of amoxicillin resistant strains and $5.3 \%$ of clarithromycin resistant strains were observed meanwhile a decrease of $6.6 \%$ in the frequency of metronidazole resistant strains isolated was detected too. Levofloxacin resistant strains also showed a mild decrease in female $(0.9 \%)$. On the other hand, among male both amoxicillin and clarithromycin resistant strains did not vary significantly their frequency of isolation during the two periods analysed. However, a significant increase of $6.4 \%$ of levofloxacin resistant strains isolated $(P=0.020)$ and a significant decrease $(P=0.019)$ of metronidazole resistant strains $(11.4 \%)$ were observed among male group in 2015-2017 period. Tetracycline resistant strains did not vary their frequency of isolation in the two periods studied, independently of the gender (TABLE 5). 
TABLE 5. Antibiotic resistant Helicobacter pylori strains isolated during a decade among female and male patients.

\begin{tabular}{|c|c|c|c|c|c|c|c|c|c|c|}
\hline & \multicolumn{10}{|c|}{ Percentage of resistant strains to } \\
\hline & \multicolumn{2}{|c|}{ Amoxicillin } & \multicolumn{2}{|c|}{ Clarithromycin } & \multicolumn{2}{|c|}{ Levofloxacin } & \multicolumn{2}{|c|}{ Metronidazole } & \multicolumn{2}{|c|}{ Tetracycline } \\
\hline & $\begin{array}{l}2005-07 \\
(n=299)\end{array}$ & $\begin{array}{c}2015-17 \\
(n=72)\end{array}$ & $\begin{array}{l}2005-07 \\
(n=333)\end{array}$ & $\begin{array}{c}2015-17 \\
(\mathrm{n}=72)\end{array}$ & $\begin{array}{l}2005-07 \\
(\mathrm{n}=321)\end{array}$ & $\begin{array}{c}2015-17 \\
(n=72)\end{array}$ & $\begin{array}{l}2005-07 \\
(\mathrm{n}=364)\end{array}$ & $\begin{array}{c}2015-17 \\
(n=72)\end{array}$ & $\begin{array}{l}2005-07 \\
(\mathrm{n}=381)\end{array}$ & $\begin{array}{r}2015-17 \\
(\mathrm{n}=72)\end{array}$ \\
\hline Female & $1.0[3]$ & $2.8[2]$ & $11.4[38]$ & $16.7\{12\}$ & $10.6[34]$ & $9.7[7]$ & $30.2[110]$ & $23.6[17]$ & $0.5[2]$ & $1.4[1]$ \\
\hline Male & $1.0[3]$ & $1.4[1]$ & $11.1[37]$ & $12.5[9]$ & $4.7[15]$ & $11.1[8]$ & $25.3[92]$ & $13.9[10]$ & $0.5[2]$ & $0[0]$ \\
\hline Total & $2.0[6]$ & $4.2[3]$ & $22.5[75]$ & $29.2[21]$ & $15.3[49]$ & $20.8[15]$ & $55.5[202]$ & $37.5[27]$ & $1.0[4]$ & $1.4[1]$ \\
\hline
\end{tabular}

\section{DISCUSSION}

The results show that clinical isolates of $H$. pylori remain susceptible to amoxicillin, with mild increase in the frequency of isolation of amoxicillin resistant $H$. pylori strains from $0 \%$ among 91 clinical isolates observed during $1999-2000^{(17)}$ to $2 \%$ in $2005-2007$ (this work, $n=299), 3.3 \%$ in 2008-2009 (27, $n=30)$, and 5.6\% in period 2015-2017 (this work, $n=72$ ). This continuous increase in the frequency of amoxicillin resistance strains among clinical $H$. pylori could be the consequence of the wide use of this antibiotic among the Chilean population. On the other hand, since we informed the first two strains of clarithromycin resistant phenotype isolated among 91 clinical isolates $(2.2 \%)$ at the Biobío-Chile region in the period 1999-2000, an increase of this resistance in clinical isolates was observed with values of $22.5 \%$ and $29.2 \%$ for the periods 2005 2007 and 2015-2017, respectively. The results were not a surprise, as suggested by Vásquez et al. ${ }^{(18)}$ and Ott et al. ${ }^{(19)}$, because when a resistance to macrolide appears for any specific pathogen in a particular geographic area, this resistance is rapidly spread and cross resistance to all macrolides is observed too. In addition, Alba et al. ${ }^{(8)}$ pointed out that patients with a history of macrolide consumption are more likely to be carriers of clarithromycin resistant strains. In addition, increasing of clarithromycin resistance could be expected due to its use in the treatment of extra-digestive infections ${ }^{(19)}$. Recently, Gonzalez-Hormazabal et al. ${ }^{(20)}$ estimated a $31.8 \%$ prevalence of clarithromycin resistance in H. pylori at Santiago-Chile by real-time PCR directly from gastric mucosa. These results are higher than the results presented in this work, but it is known that bacteriological cultures underestimate the prevalence of $H$. pylori as compared to other methods, especially as compared to PCR detection for clarithromycin. Also, Serrano et al. ${ }^{(10)}$ found infected paediatric patients at Santiago-Chile, with high prevalence of the A2143G mutation, responsible for clarithromycin resistance which is indicative of an increased prevalence of this resistance among $H$. pylori early in childhood. Regarding metronidazole resistance, a frequency of $41.8 \%$ was observed among 91 clinical strains in $1999-2000^{(17)}$, which increased to $55.5 \%$ in the $2005-2007$, but this frequency decreased to $37.5 \%$ during in period $2015-2017$. This lower frequency of metronidazole resistant has been observed by others, too ${ }^{(21)}$. The result obtained in 2015-2017 is similar to the frequency of metronidazole resistant strains informed previously by using agar dilution assay ${ }^{(22)}$. Thus, the differences in percentage of resistant strains isolated observed with metronidazole could be consequence of the method used in the assay ${ }^{(23)}$. Although disk diffusion test is not the gold standard method for determining $H$. pylori we used it, since minor variations in detecting primary resistance to clarithromycin has been observed ${ }^{(1,23,24)}$. In addition, the recommended agar dilution test-included it modified version ${ }^{(25)}$ - or the more flexible E-test ${ }^{(26)}$ assays are both time consuming or more expensive than the disk diffusion method to be used for routinely large-scale patient cohorts' analyses, especially in low resources laboratories ${ }^{(27)}$.

With respect to levofloxacin resistance, an increase of 5.5\% in the frequency of isolation in period 2015-2017 was detected. However, the resistance frequency $(20.8 \%)$ is similar to that informed in a previous work in Argentina ${ }^{(23)}$. Thus, this antibiotic could be used in triple therapies among adult Chilean patients in areas of increased eradication failures with more conventional therapies as suggested by Fallone et al. ${ }^{(28)}$, in spite of the adverse effect known to be present in long-term treatment ${ }^{(29)}$. Moreover, this substitution in the triple therapy should also be considered in geographical areas where the resistance to clarithromycin is over $20 \%$ of the clinical isolates and MET resistance frequency among clinical isolates is higher too. In those cases the recommended rescue quadruple therapy ${ }^{(7)}$ will also fail.

Our results showed the arise of simultaneous antibiotic resistant strains among clinical isolates of $H$. pylori, with increasing prevalence of resistance to clarithromycin-levofloxacin and clarithromycin-levofloxacin-metronidazole. A similar study done in Valdivia (Chile) by Ott et al. ${ }^{(19)}$ reported only five strains of $H$. pylori with resistance to clarithromycin-metronidazole and only one strain showing simultaneous resistance to three antibiotics (amoxicillin-clarithromycin-metronidazole). On the other hand, Pereira et al. ${ }^{(23)}$ informed two clinical isolates with resistance to metronidazole-clarithromycin and three to metronidazoleclarithromycin-ciprofloxacin simultaneously. The increased frequency in the isolation of multiple resistant strains including amoxicillin-clarithromycin-metronidazole resistance could be the result of the frequent use of these antibiotics in the therapy of gastric $H$. pylori infection in Chile ${ }^{(19)}$.

When gender was considered in the analyses, we found the existence of a relationship between the increment in the frequency of isolation of amoxicillin, clarithromycin and levofloxacin resistant H. pylori and female condition in 2015-2017, concomitant with a decrease of metronidazole resistant strains. On the other hand, male showed only a decrease of the metronidazole resistant isolates. Lang and García ${ }^{(12)}$ found that differences in the clinical prevalence of antibiotic resistant strains between gender at Costa Rica were not significant. Although, the authors suggested, that the difference in the level of frequency of metronidazole resistant strains isolated could be a consequence of the use of this antibiotic in gynaecological treatments. Also, the massive use of this antimicrobial agent for the treatment of other infections, such as gynaecologic, dental, gastrointestinal, giardiasis, and amoebiasis could be responsible for the development of metronidazole resistant strains among $H$. pylori isolated from females ${ }^{(19)}$. Besides, Lang and García ${ }^{(12)}$ also mentioned the existence of regional differences in the frequency of metronidazole resistance among female in Latin-America. In 
addition, the worldwide use of antibiotics increased $15 \%$ in the last 15 years, being quinolones and macrolides the most consumed ${ }^{(30)}$, exerting pressure on $H$. pylori favouring the emergence of resistant strains. This can, in part, explain the increase of amoxicillin, clarithromycin and metronidazole resistant strains in women because they are consuming more antibiotics ${ }^{(31,32)}$, therefore the likelihood of selecting resistant strains.

The results obtained in this work showed that the epidemiological patterns of the infection caused by $H$. pylori have changed within the last 10 years. Presently, the infection in men has increased when compared to the previous monitoring and that the associated diagnoses are mainly gastritis and intestinal metaplasia. Despite males continue to be the mostly affected gender; women are the group showing higher rates of resistance to antibiotics, which could be partly explained by the larger intake of them. On the other hand, to continue the regional eradication strategy, the search for alternatives to the use of clarithromycin and metronidazole is recommended because, even though the resistance to the latter is decreasing, it continues to be worryingly high. Finally, it is clear that the triple therapy in Chile, as in many other countries of the world, has become obsolete and it is being not advised in all recent revisions of the consensus, as indicated by Molina-Infante et al. ${ }^{(33)}$.

\section{CONCLUSION}

The frequency of clarithromycin resistant strains in clinical practice detected in 2015-2017 (29.2\%) suggests that conventional triple therapy is no longer effective in the Biobío-Chile region.
In addition, keeping in mind the increased resistance observed among the clinical isolates toward antibiotics most commonly used in eradication therapies in the decade, including simultaneous resistance to three and four antibiotics, we call the attention to maintain an epidemiological surveillance upon the evolution of the resistance of this highly prevent pathogen. The searching for new therapeutic alternatives and prophylactic strategies - i.e. probiotic foods, new active molecules against $H$. pylori from natural origin or the expected vaccine - are mandatory, too.

The use of levofloxacin in the triple therapy should also be considered in geographical areas, like Chile, where the resistance to clarithromycin and metronidazole is high, with increased failure of conventional eradication therapies.

\section{Authors' contribution}

Parra-Sepúlveda C: data collection, bacterial isolation, antibiotics resistance studies. Merino JS: manuscript preparation. Sáez-Carrillo K: statistical analysis. González C: data collection and manuscript preparation. García-Cancino A: data collection and manuscript preparation.

\section{Orcid}

Cristian Parra-Sepúlveda. Orcid: 0000-0002-9836-8107.

José S Merino. Orcid: 0000-0002-2797-5786.

Katia Sáez Carrillo. Orcid: 0000-0002-8580-8038.

Carlos González. Orcid: 0000-0002-9636-5586.

Apolinaria García-Cancino. Orcid: 0000-0003-3909-9733.

Parra-Sepúlveda C, Merino JS, Sáez-Carrillo K, González C, García-Cancino A. Vigilância da resistência a antibióticos contra o Helicobacter pylori na região do Biobío (Chile) em uma década. Arq Gastroenterol. 2019;56(4):361-6.

RESUMO - Contexto - A infecção por Helicobacter pylori no Chile permanece como um desafio do sistema de saúde público e privado, com prevalência da infecção acima de 70\%. Hoje em dia, o tratamento antibiótico da infecção é obrigatório para prevenir o surgimento de graves doenças associadas, mas falhas na terapia de erradicação, principalmente devido à resistência à claritromicina, têm sido observadas em todo o mundo, e a terapia de erradicação de primeira linha parece não ser mais eficaz em várias áreas geográficas. Assim, os sistemas de saúde estão comprometidos em manter uma vigilância epidemiológica sobre a evolução da resistência aos antibióticos deste patógeno prioritário tipo 2. Objetivo - Este trabalho relata uma vigilância de 10 anos da resistência antibiótica primária de isolados clínicos de H. pylori na região do Biobío-Chile, e a evolução da resistência em relação à amoxicilina, claritromicina, levofloxacina, metronidazol e tetraciclina entre as espécies. Métodos - As cepas de $H$. pylori foram investigadas durante os períodos 2005-2007 (1435 pacientes analisados) e 2015-2017 (220 pacientes analisados) inoculando uma biópsia de homogeneizado fisiológico na superfície do agar Columbia (Oxoid, Basingstoke, Reino Unido) - suplementado com 7\% de glóbulos vermelhos do cavalo mais o inibidor de DENTE (Oxoid, Basingstoke, Reino Unido) - seguindo pela incubação em $37^{\circ} \mathrm{C}$ a atmosfera de $10 \%$ de $\mathrm{CO}_{2}$ por cinco dias. O padrão de resistência aos antibióticos dos isolados foi avaliado utilizando-se o teste de difusão em disco em agar Müeller-Hinton suplementado com 7\% de glóbulos vermelhos de cavalo seguidos de incubação por mais três dias a atmosfera de $10 \%$ de $\mathrm{CO}_{2}$. A análise estatística foi realizada utilizando-se o software SPSS V22 e os valores de $P<0,5$ foram considerados estatisticamente significantes. Resultados - Um total de $41 \%$ dos 1435 pacientes foram detectados como contaminados por $H$. pylori pela cultura bacteriológica no período $2005-2007$, ao mesmo tempo $32,7 \%$ de 220 pacientes foram contaminados igualmente no período 2015-2017. Os isolados clínicos de H. pylori são principalmente suscetíveis à amoxicilina e tetraciclina (tanto mais de $98 \%$ das cepas), mas menos suscetíveis à levofloxacina em ambos os períodos analisados (mais de $79 \%$ das cepas). Por outro lado, o metronidazol permaneceu mostrando a maior pontuação de resistentes isolados (mais de $40 \%$ de cepas resistentes), embora tenham sido observados $18 \%$ menos cepas resistentes no período de 2015-2017. A claritromicina, o antibiótico-chave em terapias de erradicação, tem uma frequência aumentada de cepa resistente isolada na década (22,5\% em 2005-2007 e 29,2\% em 2015-2017). Cepas multirresistentes (dois, três e quatro antibióticos) também foram detectadas em ambos os períodos com os maiores escores de resistência simultânea à claritromicina-metronidazol (18\%) e claritromicina-metronidazol-levofloxacina (12,5\%) cepas resistentes. De acordo com o sexo, os isolados resistentes à amoxicilina, claritromicina e metronidazol foram mais frequentes no sexo feminino, com incremento específico em amoxicilina e resistência à claritromicina. Conclusão - A frequência de resistência à claritromicina (29,2\%) detectada em 2015-2017 sugere que a terapia tripla convencional não é mais efetiva nesta região.

DESCRITORES - Helicobacter pylori, efeitos dos fármacos. Infecções por Helicobacter. Antibacterianos. Farmacorresistência bacteriana. Claritromicina. Homens. Mulheres. Chile. 


\section{REFERENCES}

1. Camargo MC, García A, Riquelme A, Otero W, Camargo CA, Hernandez-García T, Candia R, Bruce MG, Rabkin CS. The problem of Helicobacter pylori resistance to antibiotics: a systematic review in Latin America. Am J Gastroenterol 2014;109:485-95.

2. Ferreccio C, Rollán A, Harris PR, Serrano C, Gederlini A, Margozzini P, et al. Gastric cancer is related to early Helicobacter pylori infection in a high-prevalence country. Cancer Epidemiol Biomarkers Prev. 2007;16:662-7.

3. Porras C, Nodora J, Sexton R, Ferreccio C, Jimenez S, Dominguez RL, et al Epidemiology of Helicobacter pylori infection in six Latin American countries (SWOG Trial S0701). Cancer Causes Control. 2013;24:209-15.

4. Ministerio de Salud. Tratamiento de erradicación de Helicobacter pylori en el paciente con ulcera péptica. Serie Guías Clínicas MINSAL. 2013:1-44.

5. Merino JS, Araneda L, Lincoñir-Campos P, Parra C, Sáez K, García A. Dinámica de la infección por Helicobacter pylori en lactantes durante los primeros seis meses de vida. Enfermedades Infecciosas y Microbiología Clínica. 2019;37:109-11.

6. Malfertheiner P, Megraud F, O'Morain CA, Gisbert JP, Kuipers EJ, Axon AT, Bazzoli F, et al. Management of Helicobacter pylori infection-the Maastricht IV/Florence Consensus Report. Gut. 2012;61:646-64.

7. Malfertheiner P, Megraud F, O’Morain CA, Gisbert JP, Kuipers EJ, Axon AT, et al. European Helicobacter and Microbiota Study Group and Consensus panel. Management of Helicobacter pylori infection-the Maastricht V/Florence Consensus Report. Gut. 2017;66:6-30.

8. Alba C, Blanco A, Alarcón T. Antibiotic resistance in Helicobacter pylori. Curr Opin Infect Dis. 2017;30:489-97.

9. Tacconelli E, Carrara E, Savoldi A, Harbarth S, Mendelson M, Monnet D, et al, and the WHO Pathogens Priority List Working Group. Discovery, research, and development of new antibiotics: the WHO priority list of antibiotic-resistant bacteria and tuberculosis. Lancet Infect Dis. 2018:18;318-27.

10. Serrano CA, Leon MA, Palma C, Vera M, Hernandez C, Harris PR. Helicobacte pylori-clarithromycin resistance in symptomatic paediatric patients in a High Prevalence Country. J Pediatr Gastroenterol Nutr. 2017;64:e56-e60.

11. Schnell G, Shubert T. Usefulness of culture, histology, and urease testing in detection of C. pyloridis. Am J Gastroenterol. 1989;84:132-7.

12. Lang L, García F. Comparison of E-Test and disk diffusion assay to evaluate resistance of Helicobacter pylori isolates to amoxicillin, clarithromycin, metronidazole and tetracycline in Costa Rica. Int J Antimicrob Ag. 2004;24:572-7.

13. Chaves S, Gadanho M, Tenreiro R, Cabrita J. Assessment of metronidazole susceptibility in Helicobacter pylori: Statistical validation and error rate analysis of breakpoints determined by disk diffusion test. J Clin Microbiol. 1999;37:1628-31

14. Yepes CA, Rodríguez A, Ruiz A, Ariza B. Resistencia antibiótica del Helicobacter pylori en el Hospital Universitario San Ignacio de Bogotá. Acta Méd Colomb. 2008:33:11-4.

15. Pfaller MA, Barry AL, Fuchs PC. Levofloxacin disk potency and interpretative criteria for susceptibility tests. J Clin Microbiol. 1993;31:1924-6.

16. Yu C, Li L, Chen W, Jiao Y, Yang N, Yang E, et al. Levofloxacin susceptibility testing for Helicobacter pylori in China: Comparison of E-Test and disk diffusion method. Helicobacter. 2011;16:119-23.

17. González CC, García CA, Daroch MF, Kawaguchi PF, Solar RH, Rivera FN, et al. Susceptibilidad in vitro de cepas de Helicobacter pylori: aislamiento de cepas resistentes a claritromicina. Rev Méd Chile. 2001;129:643-6.
18. Vásquez A, Valdez Y, Gilman RH, McDonald JJ, Westblom TU, Berg D, et al Metronidazole and clarithromycin resistance in Helicobacter pylori determined by measuring MICs of antimicrobial agents in color indicator egg yolk agar in a miniwell format. The Gastrointestinal Physiology Working Group of Universidad Peruana Cayetano Heredia and the Johns Hopkins University. J Clin Microbiol. 1996;34:1232-4.

19. Otth L, Wilson M, Fernández H, Otth C, Toledo C, Cárcamo V, et al. Isolation of Helicobacter pylori in gastric mucosa and susceptibility to five antimicrobial drugs in Southern Chile. Braz J Microbiol. 2011;42:442-7.

20. Gonzalez-Hormazabal P, Musleh M, Escandar S, Valladares H, Lanzarini E, Castro GV, et al. Prevalence of clarithromycin resistance in Helicobacter pylori in Santiago, Chile, estimated by real-time PCR directly from gastric mucosa. BMC Gastroenterol. 2018;18:91.

21. Dan W, Guo Q, Yuan Y, Gong Y. The antibiotic resistance of Helicobacter pylori to five antibiotics and influencing factors in an area of China with a high risk of gastric cancer. BMC Microbiol. 2019;19:152-62.

22. Soto A, García A, González CL. In vitro Antagonism of Rabeprazole and Metronidazole upon Clinical Isolates of Helicobacter pylori. Chemother. 2009;55:308-11.

23. Pereyra LV, Gorordo Ipiña RC, Berruezo FA, Amieva CA, García ME, Bottiglier MT. Sensibilidad a los antimicrobianos de aislamientos de Helicobacter pylori aislados de lesiones gástricas. Rev Argent Microbiol. 2017;49:153-7.

24. Ogata S, Gales A, Kawakami E. Antimicrobial susceptibility testing for Helicobacter pylori isolates from Brazilian children and adolescents: Comparing agar dilution, E-test, and disk diffusion. Braz J Microbiol. 2014;45:1439-48.

25. Di Giulio M, Di Campli E, Di Bartolomeo S, Cataldi V, Marzio L, Grossi L, et al. In vitro antimicrobial susceptibility of Helicobacter pylori to nine antibiotics currently used in Central Italy. Scand J Gastroenterol. 2016;51:263-9.

26. Ducournau A, Benejat L, Sifre E, Ducournau A, Benejat L, Sifre E. Helicobacter pylori resistance to antibiotics in 2014 in France detected by phenotypic and genotypic methods. Clin Microbiol Infect. 2016;22:715-8.

27. Boyanova L, Ilieva J, Gergova G, Mitov I. Levofloxacin susceptibility testing against Helicobacter pylori: evaluation of a modified disk diffusion method compared to E test. Diagn Microbiol Infect Dis. 2016;84:55-6.

28. Fallone C, Steven F, Moss, Malfertheiner. Reconciliation of Recent Helicobacter pylori Treatment Guidelines in a Time of Increasing Resistance to Antibiotics. Gastroenterology. 2019, Apr 15. pii: S0016- 5085(19)35704-X.

29. European Medicine Agency (EMA). Disabling and potentially permanent side effects lead to suspension or restrictions of quinolone and fluoroquinolone antibiotics [11 March 2019].

30. Klein EY, Van Boeckel TP, Martinez EM, Pant S, Gandra S, Levin SA, et al Global increase and geographic convergence in antibiotic consumption between 2000 and 2015. PNAS. 2018;115(15):E3463-E3470.

31. Lallana MJ, Feja C, Malo S, Abad JM, Bjerrum L, Rabanaque MJ. Variabilidad de la prescripción de antibióticos en atención primaria de los sectores sanitarios de Aragón. Revista Española de Salud Pública. 2012;86:627-35.

32. Serna MC, Ribes E, Real J, Galván L, Gascó E, Godoy P. Alta exposición a antibióticos en la población y sus diferencias por género y edad. Atención Primaria. 2011:43:236-44

33. Molina-Infante J, Corti R, Doweck J, McNicholl A, Gisbert J. Avances recientes en el tratamiento de la infección por Helicobacter pylori. Acta Gastroenterol Latinoam 2017;47:75-85. 